Supplement of Biogeosciences, 14, 2283-2292, 2017

http://www.biogeosciences.net/14/2283/2017/

doi:10.5194/bg-14-2283-2017-supplement

(C) Author(s) 2017. CC Attribution 3.0 License.

(c) (i)

Supplement of

\title{
The origin of methane in the East Siberian Arctic Shelf unraveled with triple isotope analysis
}

Célia J. Sapart et al.

Correspondence to: Célia J. Sapart (csapart@ulb.ac.be)

The copyright of individual parts of the supplement might differ from the CC-BY 3.0 licence. 


\section{SUPPLEMENTARY INFORMATION}

\section{DEEP CORE LITHOLOGY}

Table S1 shows the coordinates, bathymetry, distance from the coast and inundation time data of the deep cores. The major differences in the lithology of the deep cores drilled in 2011 and 2013 are the thickness and the origin of the Holocene age sediment. In the non-ebullition core, Holocene age marine sediments compose the upper $5.5 \mathrm{~m}$. They represent disperse pelitealeurite deposits predominantly of alluvial origin, which are accumulations of river-derived matter formed in coastal marine conditions with high rates of sediment accumulation (Fig.S1). Holocene sediments are underlain with terrestrial accumulations $(5.8 \mathrm{~m}$ to $52.3 \mathrm{~m})$ of late Pleistocene age, which are represented by consolidated aleuro-sands inter-layered by fine-grained aleurite accumulations with inclusions of pebbles and wood remains.

The other deep cores (the hotspot cores) were drilled in 2013 near the Muostakh Island. In the IID-13 and IIID-13 cores, the Holocene age sediments represent only the upper $0.5 \mathrm{~m}$ and consist of remains of the coastal ice-complex (IC or Yedoma) of Muostakh Island. This area represents a former part of the coastal alluvial plain, the upper part of which is composed of IC that thaws very fast during the last century. Sediment morphology reflects the nature of the sediments: fine-grained sand-aleurite-pelite is interlayered with gravel-pebble material with inclusions of wood remains and plant debris.

Sediment core VD-13 stands out of all the other cores drilled in 2013. Its morphological structure is different as its frozen fraction is presented by sands interlayered by gravel-pebble accumulations.

\section{INTERPRETATION OF THE ${ }^{14} \mathrm{C}-\mathrm{CH}_{4}$ RESULTS}

The observation of unexpectedly high ${ }^{14} \mathrm{C}$ values for the ID-11 nonebullition core and water samples from the shelf edge needs further discussion. As explained in the main text, ${ }^{14} \mathrm{C}$ values $>200 \mathrm{pmC}$ do not exist in nature in any carbonaceous material including $\mathrm{CH}_{4}$, not even at the height of surface nuclear bomb tests of the mid- $20^{\text {th }}$ century. We assume that a local anthropogenic nuclear contribution is the most likely explanation for our elevated radiocarbon levels, which is justified in this section.

In the ID-11 non-ebullition sediment, the higher ${ }^{14} \mathrm{C}$ values correspond to the lower $\mathrm{CH}_{4}$ concentrations (Fig. S5). That implies a possible mixture between a older $\mathrm{CH}_{4}$ source and a background highly enriched in ${ }^{14} \mathrm{C}$. A Keeling plot shows that the highly enriched ${ }^{14} \mathrm{C}$ contribution is relatively small in terms of $\mathrm{CH}_{4}$ quantity and that the main $\mathrm{CH}_{4}$ substrate is relatively old (Fig. S5). For the hotspot sites, where $\mathrm{CH}_{4}$ concentrations are larger, no mixture with a "younger" source is identified. All data points are showing very low ${ }^{14} \mathrm{C}$ $(<1.5 \mathrm{pmC})$ so the main $\mathrm{CH}_{4}$ substrate at these sites is clearly of Pleistocene age. Note that all points of the IID-13 core were below the analytical detection limit of $0.8 \mathrm{pmC}$ hence no conclusions could be drawn from the Keeling plot of this core. 
The very high ${ }^{14} \mathrm{C}$ values $>200 \mathrm{pmC}$ may either originate from in situ cosmogenic or nuclear production of radioactive $\mathrm{CH}_{4}$ or its substrate. Enhanced ${ }^{14} \mathrm{C}$ has been found in meteorites (Firemann, 1978) and can be produced at the surface of ice sheets (e.g. Fireman and Norris et al., 1982), but in both cases, the quantity of ${ }^{14} \mathrm{C}$ formed is very small compare to what we observed in the Buor-Khaya Bay and shelf edge sediment and water samples. Nuclear production of ${ }^{14} \mathrm{C}$ involves formation by neutron activation as consequence of a nuclear chain reaction, which may either take place naturally or artificially. In the atmosphere, cosmic rays can also produce neutrons which can react with ${ }^{14} \mathrm{~N}$ to produce ${ }^{14} \mathrm{C}$. The only place on Earth, where evidence of a natural nuclear reactor has been found is in Oklo, Gabon (Baudin et al., 1972, Cowan, 1976, Kuroda, 1982). However, such natural reactors cannot be active anymore today, as the relative abundance of fissile ${ }^{235} \mathrm{U}$ has now decayed below that required threshold for a sustainable nuclear reaction chain.

The Arctic Ocean has been used as a disposal area for radioactive wastes (Nuclear Wastes in the Arctic report, 1995, Johnson-Pyrtle and Scott, 1991). We therefore believe that anthropogenic nuclear contamination is the most likely explanation for these ${ }^{14} \mathrm{C}$-enriched $\mathrm{CH}_{4}$ background contribution. Similar cases but with slightly lower values have been observed in gas samples from marine basins along the Californian coast (Kessler et al., 2008). We suggest that nuclear anthropogenic contamination could have been laterally transported from thawing terrestrial permafrost in the pore-water of the thawing subsea permafrost in the form of $\mathrm{CH}_{4}$ or of one of its precursors (e.g. dissolved inorganic carbon) to our drilling site and further on the shelf. Note that more data, e.g. of other radionuclides would be essential to confirm this interpretation.

We exclude a possible contamination during sampling, extraction and analysis, because no radioactive tracers were used during the sampling expeditions. The samples affected by enriched ${ }^{14} \mathrm{C}$ values were not sampled in a similar manner. The sediment samples were drilled from the ice in 2011 while the shelf edge water samples were sampled in 2012 from a ship together with other water and surface sediment samples showing no enrichment in ${ }^{14} \mathrm{C}$ values. For the rest of the sampling and analysis process, all samples were handled in a similar way and measured in a random order, but only samples from these two specific locations show highly enriched ${ }^{14} \mathrm{C}$ values. None of the reference and blank measurements were abnormal either. 


\section{SUPLEMENTARY REFERENCES}

Baudin, G., Blain, C., Hagemann, R., Kremer, M., Lucas, M., Merlivat, L., Molina, R., Nieff, G., Prost Marechal, P., Regnaud, F. \& Roth, E.: Quelques données nouvelles sur les reactions nucléaires en chaine que se sont produites dans le gisement d'Oklo, C.R. Acad. Sci. Paris, 275D, 2291, 1973.

Cowan, George A.: A natural fission reactor, Scientific American, 235.1, 3647,1976 .

Firemann, E. L.: Carbon-14 in lunar soil and in meteorites, Proc. Lunar Planet. Sci. Conf. $9^{\text {th }}, 1647-1654,1978$.

Fireman, E.L., and Norris, T.L.: Ages and composition of gas trapped in Allan Hills and Byrd core, Earth and Planetary Science Letters, 60, 339-350, 1982.

Johnson-Pyrtle, A. and Scott, M.R.: Distribution of $137 \mathrm{Cs}$ in the Lena River Estuary-Laptev Sea System, Marine Pollution Bulletin Vol. 42, No. 10, pp. 912-926, 2001.

Kessler, J. D., Reeburgh, W.S., Valentine, D.L., Kinnaman, F.S., Peltzer, E.T., Brewer, P.G., Southon, J. \& Tyler, S.C.: A survey of methane isotope abundance $\left({ }^{14} \mathrm{C},{ }^{13} \mathrm{C},{ }^{2} \mathrm{H}\right)$ from five nearshore marine basins that reveals unusual radiocarbon levels in subsurface waters, J. Geophys. Res.,113, C12021, 2008.

Kuroda, P. K.: The Oklo phenomenon." The Origin of the Chemical Elements and the Oklo Phenomenon, Springer Berlin Heidelberg, 31-55, 1982.

Nuclear Wastes in the Arctic: An Analysis of Arctic and Other Regional Impacts from Soviet Nuclear Contamination, OTA-ENV-623 (Washington, DC: U.S. Government Printing Office, September), 1995. 


\begin{tabular}{|c|c|c|c|c|c|c|c|}
\hline $\begin{array}{l}\text { Borehole/s } \\
\text { helf area } \\
\text { of } \\
\text { sampling }\end{array}$ & Latitude & Longitude & $\begin{array}{l}\text { Water } \\
\text { depth, } \\
\mathrm{m}\end{array}$ & $\begin{array}{c}\text { Water } \\
\text { temperature } \\
\text { surface/ } \\
\text { bottom }\end{array}$ & $\begin{array}{l}\text { Water } \\
\text { salinity } \\
\text { surface/ } \\
\text { bottom }\end{array}$ & $\begin{array}{c}\text { Time } \\
\text { since } \\
\text { inundation }\end{array}$ & $\begin{array}{l}\text { Distance } \\
\text { from the } \\
\text { shore, } \mathrm{km}\end{array}$ \\
\hline ID-11 & 71,6926 & 130,3669 & 12.5 & $-0.52 /-0.92$ & $10.8 / 19.4$ & $\sim 8 \div 7$ kyr BP & $\begin{array}{c}18.6 \mathrm{~km} \\
\text { from Muo- } \\
\text { stakh Isl and } \\
39.8 \mathrm{~km} \\
\text { from } \\
\text { Bykovsky } \\
\text { Peninsula }\end{array}$ \\
\hline IID-13 & 71,6288 & 129,8534 & 2.5 & $-0.41 /-0.61$ & $12.8 / 13.2$ & $\sim 7 \div 6$ kyr BP & $2.5 \mathrm{~km}$ \\
\hline IIID-13 & 71,6219 & 129,8517 & 4.1 & $-0.40 /-0.61$ & $12.8 / 13.2$ & $\sim 7 \div 6$ kyr BP & $2.5 \mathrm{~km}$ \\
\hline VD-13 & 71,7449 & 129,4048 & 3.6 & $-1.01 /-1.03$ & $22.6 / 22.6$ & $\begin{array}{c}\text { Lagoon, } \\
\sim 7 \div 6 \text { kyr BP } \\
\text { (Romanovsky et } \\
\text { al., 1999) }\end{array}$ & $\begin{array}{l}\text { Lagoon } \\
\text { adjacent to } \\
\text { the coast }\end{array}$ \\
\hline $\begin{array}{c}\text { Lena } \\
\text { Delta } \\
\text { Str. } 42 * \\
47 * \\
70 * * \\
71 * * \\
\end{array}$ & $\begin{array}{l}72,977 \\
72,427 \\
72.687 \\
72.683 \\
\end{array}$ & $\begin{array}{l}130,141 \\
130,151 \\
130.640 \\
130.267 \\
\end{array}$ & $\begin{array}{l}12.5 \\
8.5 \\
20 \\
12 \\
\end{array}$ & $\begin{array}{l}3.74 / 1.42 \\
4.42 / 2.53 \\
2.40 / 2.83 \\
1.02 / 2.47 \\
\end{array}$ & $\begin{array}{c}16.3 / 22.3 \\
0.5 / 4.6 \\
19.0 / 21.5 \\
9.0 / 19.1 \\
\end{array}$ & $\sim 7 \div 6 \mathrm{kyr} \mathrm{BP}$ & 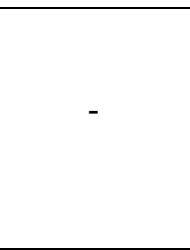 \\
\hline $\begin{array}{c}\text { Dmitry } \\
\text { Laptev } \\
\text { Str. } 31 * \\
36 * \\
79 * * \\
80 * * \\
81 * * \\
82 * * \\
83 * * \\
84 * * \\
85 * * \\
\end{array}$ & $\begin{array}{l}72,882 \\
73,118 \\
73.030 \\
73.169 \\
73.316 \\
73.297 \\
73.104 \\
72.930 \\
72.886 \\
\end{array}$ & $\begin{array}{l}140,620 \\
139,517 \\
139.393 \\
139.574 \\
139.768 \\
140.085 \\
140.352 \\
140.619 \\
140.643 \\
\end{array}$ & $\begin{array}{c}15.5 \\
13.5 \\
15.0 \\
15 \\
9 \\
11 \\
14 \\
12 \\
24 \\
\end{array}$ & $\begin{array}{c}3.38 / 3.76 \\
3.30 / 3.44 \\
1.92 / 3.04 \\
1.67 / 2.42 \\
1.85 / 1.79 \\
1.6 / 1.46 \\
1.75 / 2.19 \\
1.77 / 1.77 \\
1.69 / 1.77 \\
\end{array}$ & $\begin{array}{c}18.7 / 20.3 \\
19.8 / 24.0 \\
19.8 / 23.3 \\
19.3 / 26.7 \\
18.6 / 24.8 \\
24.17 / 26.4 \\
20.3 / 26.5 \\
21.1 / 21.1 \\
20.8 / 20.9 \\
\end{array}$ & $\sim 8 \div 7$ kyr BP & - \\
\hline $\begin{array}{l}\text { Buor- } \\
\text { Khaya } \\
\text { Gulf }\end{array}$ & $\begin{array}{l}\text { Drilling } \\
\text { sites }\end{array}$ & & & & & $\sim 8 \div 7 \mathrm{kyr} \mathrm{BP}$ & - \\
\hline $\begin{array}{c}\text { Shelf edge } \\
\text { Sts. } 9^{*} \\
13^{*} \\
28^{* *} \\
32^{* *} \\
36^{* *} \\
37^{* *}\end{array}$ & $\begin{array}{l}76,897 \\
76,894 \\
77.000 \\
77.029 \\
76.398 \\
76.648\end{array}$ & $\begin{array}{c}127,8047 \\
127,8032 \\
125.985 \\
127.289 \\
125.051 \\
125.048 \\
\end{array}$ & $\begin{array}{l}62 \\
63 \\
91 \\
74 \\
62 \\
70 \\
\end{array}$ & $\begin{array}{l}3.54 /-1.33 \\
3.47 /-1.40 \\
3.87 /-0.82 \\
3.00 /-1.21 \\
1.26 /-1.17 \\
1.89 /-1.19\end{array}$ & $\begin{array}{l}28.0 / 33.4 \\
29 / 1 / 33.3 \\
28.8 / 34.4 \\
21.9 / 34.2 \\
19.0 / 34.1 \\
17.3 / 34.2\end{array}$ & $\sim 15 \div 13$ kyr BP & - \\
\hline
\end{tabular}




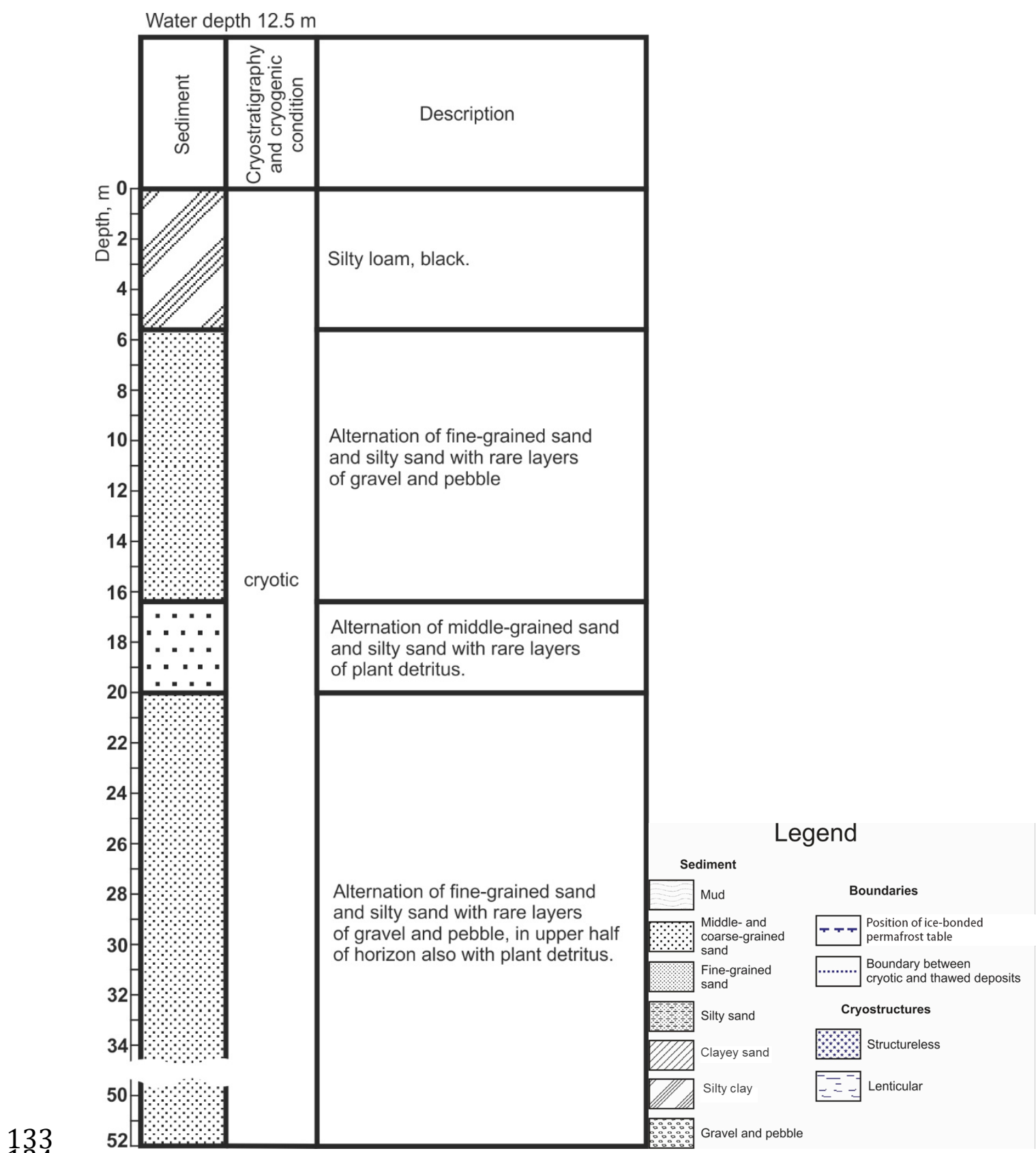

Figure S1: Lithology and cryostratigraphy of the sediment core recovered from the borehole ID-11 in the near-shore zone of the ESAS. Ice-bonded permafrost table was not reached during the drilling. The sediments from 0 to $52 \mathrm{~m}$ below the seafloor were cryotic, that is unfrozen under temperatures $<0^{\circ} \mathrm{C}$. 
Water depth $2.5 \mathrm{~m}$

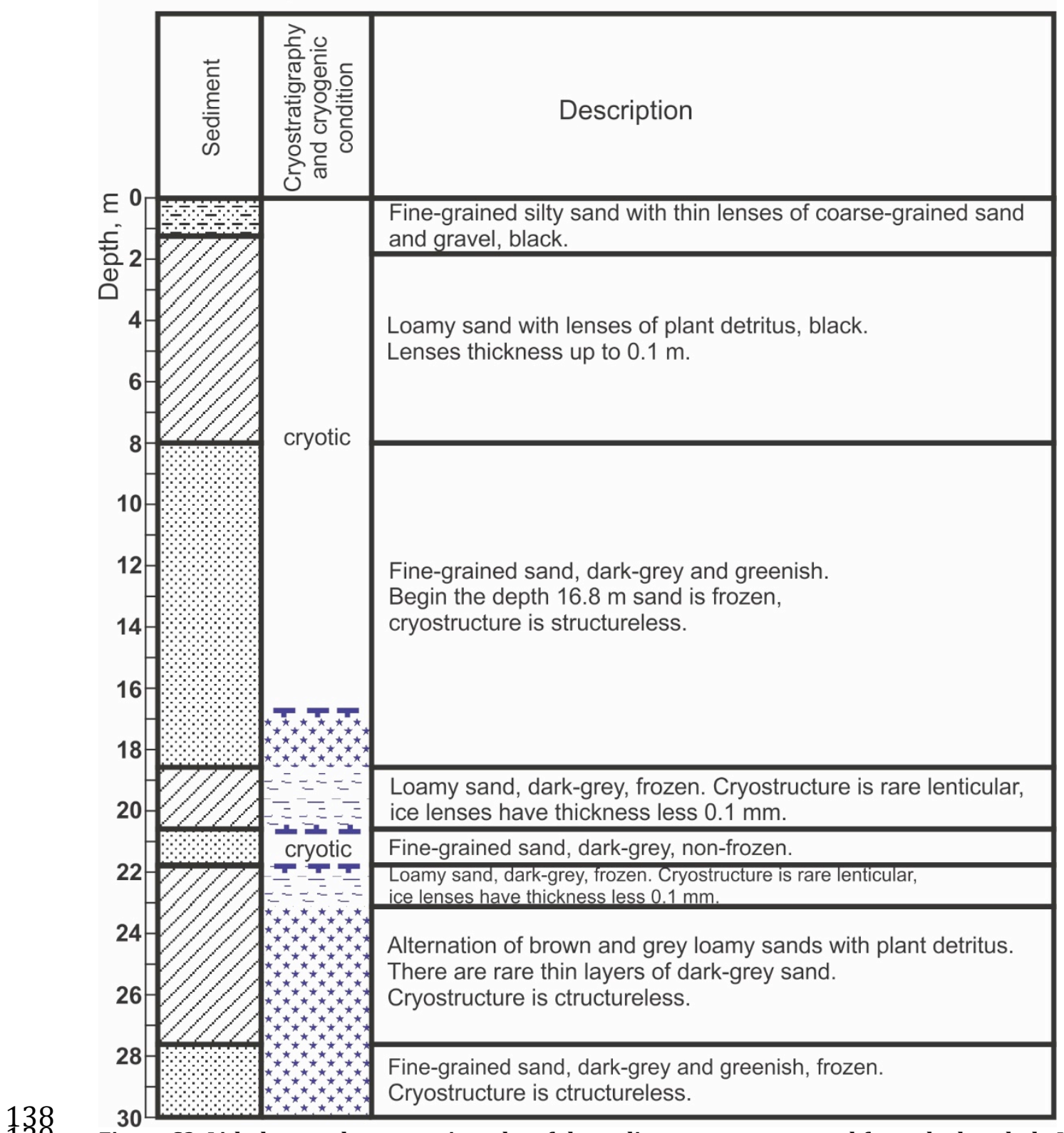

Figure S2. Lithology and cryostratigraphy of the sediment core recovered from the borehole IID-13 in the near-shore zone of the ESAS. Ice-bonded permafrost table was reached at $16.4 \mathrm{~m}$ below the seafloor during the drilling. The sediments from $0 \mathrm{~m}$ to $16.4 \mathrm{~m}$ below the seafloor were cryotic, that is unfrozen under temperatures $<0^{\circ} \mathrm{C}$. A thin layer $(1.2 \mathrm{~m})$ of cryotic sediments was also observed at depth of $20.5 \mathrm{~m}$ below the seafloor. Legends, see Fig. S1. 


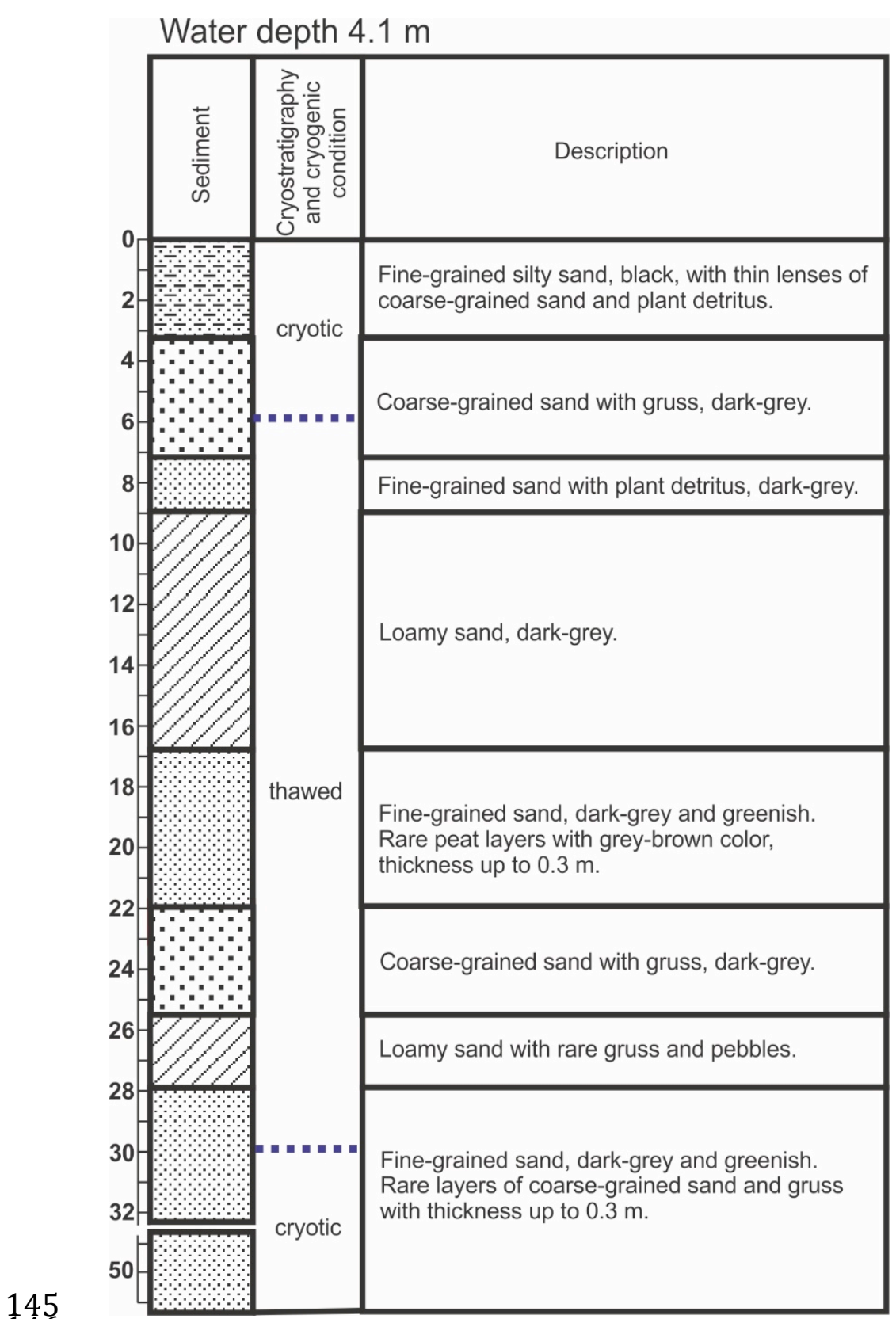

Figure S3. Lithology and cryostratigraphy of the sediment core recovered from the borehole IIID-13 in the near-shore zone of the ESAS. Ice-bonded permafrost table was not reached during the drilling. The sediments from $0 \mathrm{~m}$ to $51 \mathrm{~m}$ below the seafloor were cryotic from 0 to $6 \mathrm{~m}$ below the seafloor; thawed (that is unfrozen under temperatures $>0^{\circ} \mathrm{C}$ ) from 6 to $30 \mathrm{~m}$ below the seafloor and cryotic from 30 to $51 \mathrm{~m}$ below the seafloor. Legends, see Fig. S1. 


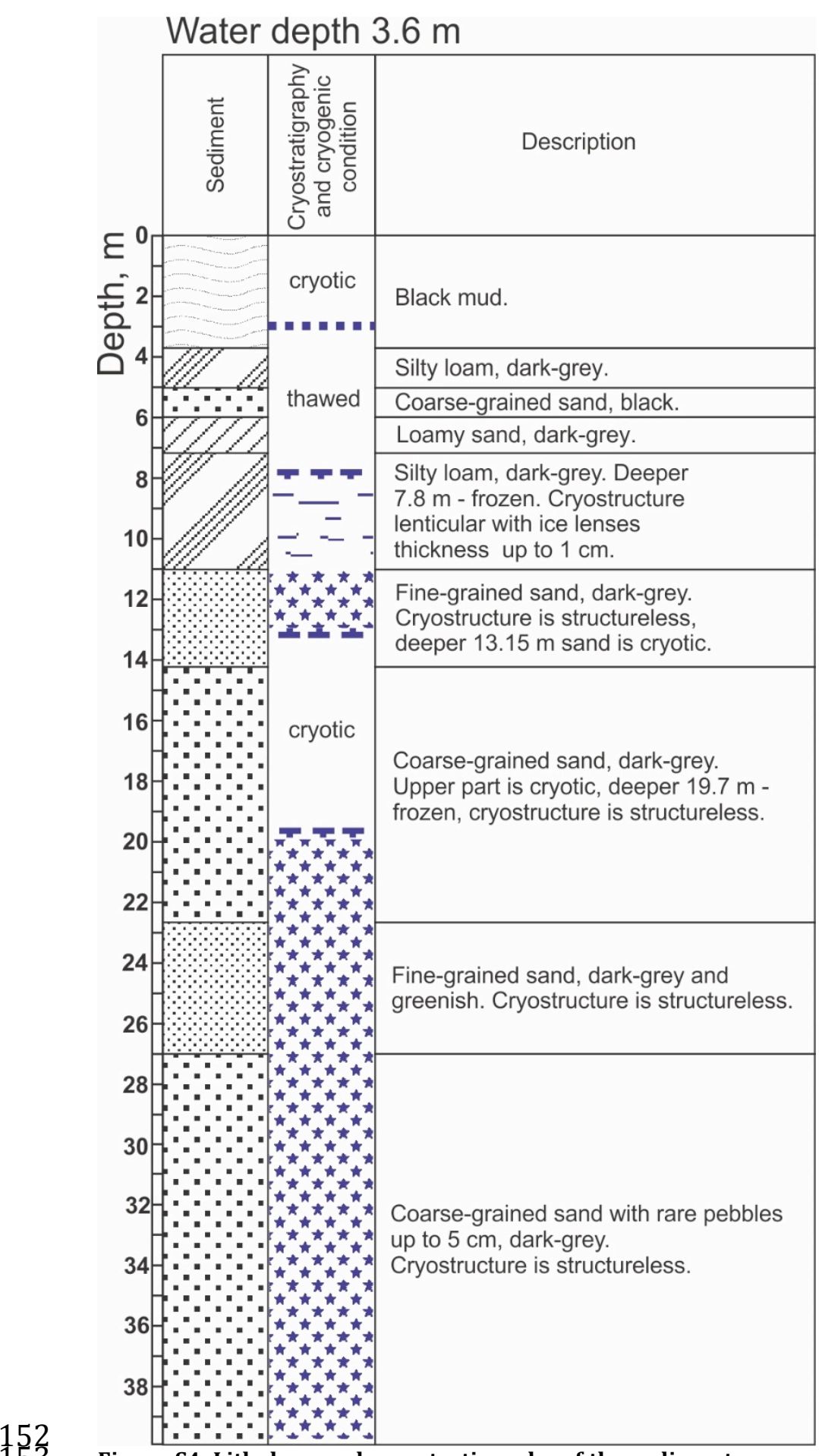

Figure S4. Lithology and cryostratigraphy of the sediment core recovered from the borehole VD-13 in the near-shore zone of the ESAS. Ice-bonded permafrost table was reached at $7.8 \mathrm{~m}$ below the seafloor during the drilling. The sediments from $0 \mathrm{~m}$ to $3 \mathrm{~m}$ below the seafloor were cryotic; from 3 to 7.8 - frozen; within frozen sediments, the layer of cryotic sediments was observed from 13 to 19.5 $\mathrm{m}$ below the seafloor. Legends, see Fig. $\mathrm{S1}$. 


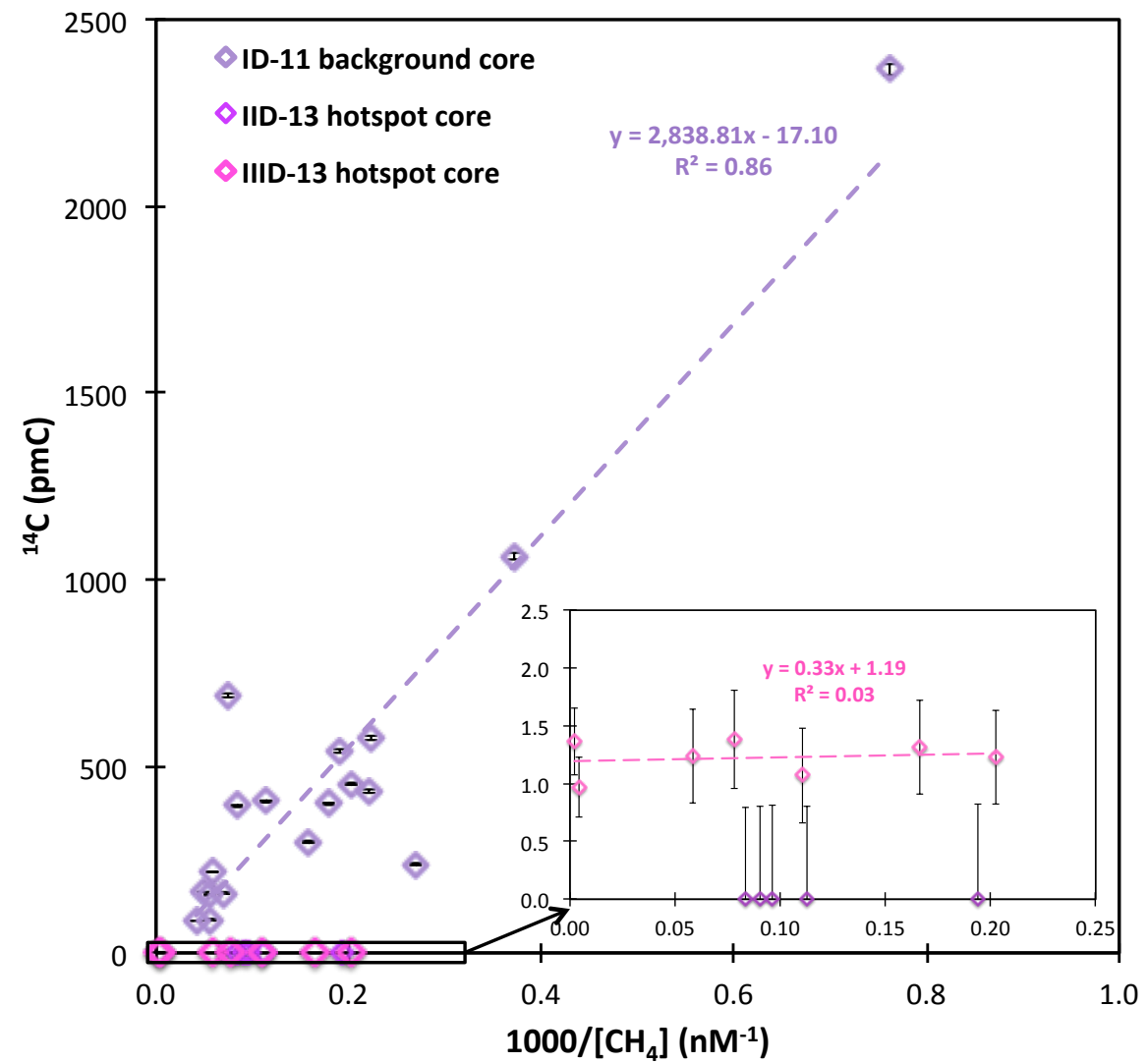

Figure S5: Keeling plot: inverse $\mathrm{CH}_{4}$ concentration versus ${ }^{14} \mathrm{C}$ data for sediment samples in the partially thawed subsea permafrost. The diamonds are "deep" core sediment data and the dashed lines represent the linear regressions for the ID-11 (purple) and IIID-13 (pink) cores. All values of the IID-13 core are close to zero so no linear regression line is depicted for this core. The intersections with the $\mathrm{y}$-axis correspond to the ${ }^{14} \mathrm{C} \mathrm{pmC}$ values of the main $\mathrm{CH}_{4}$ substrate. 